\title{
Outline of The Ground Water Occurrences Beneath the area Around Ain Zubida by Integration of Magnetic, Electrical Resistivity Sounding, and Seismic Refraction Methods
}

\author{
T.A. Mokhtar, H.I. Hassanein and M.M. Alsaeed \\ Geophysics Department, Faculty of Earth Sciences, \\ King Abdulaziz University, Jeddah, Saudi Arabia
}

Received: 16/3/2002 Revised: 5/3/2003 Accepted: 8/4/2003

Abstract. Ain Zubida lies in Wadi Numan east of Arafat, Makkah AlMukarramah, K.S.A. The study area is located between latitudes $21^{\circ} 17^{\prime}-21^{\circ} 24^{\prime} \mathrm{N}$ and longitudes $40^{\circ} 00^{\prime}-40^{\circ} 10^{\prime} \mathrm{E}$. Wadi Numan discharges its water to the Red Sea. The area under investigation forms a part of the Arabian Shield of the Western Saudi Arabia. Accordingly, igneous and metamorphic rocks cover the study area. In the upstream of Wadi Numan, the escarpment is a conspicuous structural feature; besides, major and minor faults are dominant in Wadi Numan and adjacent areas.

The aim of this study is to define the distribution of ground water around Ain Zubida, and to select suitable locations for drilling exploratory wells. Therefore, the integration among ground magnetic, resistivity and seismic refraction methods is used to obtain the most useful results.

The ground magnetic survey conducted along eight profiles across Wadi Numan indicates that the depth of basement rocks in the area under investigation ranges between 25 and $121 \mathrm{~m}$. The magnetic method was also used to define the main structural zones and the relatively thick sedimentary cover which affect the ground water distribution.

The vertical electrical sounding survey was conducted at 62 sites. This survey led to classifying the alluvium covering the basement rocks, according to its resistivity values, into two layers. The upper layer has relatively high resistivity values and the lower has relatively low values. This latter is expected to be water-saturated. 


\begin{abstract}
The seismic refraction method was used at three selected sites to emphasize the structures, layering and water saturation at those sites. The present study revealed the presence of a graben structure in Wadi Numan. This structure acts as a channel stream of water accumulation. Accordingly, this study suggests a number of suitable locations for exploratory drilling.
\end{abstract}

\title{
Introduction
}

Ain Zunida lies in Wadi Numan east of Arafat, Makkah Al-Mukarramah, K.S.A. The study area is located between latitudes $21^{\circ} 17^{\prime}-21^{\circ} 24^{\prime} \mathrm{N}$ and longitudes $40^{\circ} 00^{\prime}-40^{\circ} 10^{\prime} \mathrm{E}$. The main access to the area is through Makkah-Mina and Arafat highways. Wadi Numan discharges its water to the Red Sea (Fig. 1).

The area under investigation forms a part of the Arabian Shield in Western Saudi Arabia. Except for the strips occupied by wadis, the study area is covered by igneous and metamorphic rocks (Brown et al., 1963). In the upstream of Wadi Numan, the escarpment is a conspicuous structural feature. Major and minor faults dominate the escarpment, as well as, the adjacent areas. Figure (2) shows the main topography of the area under study. Wadi Numan is surrounded by a number of mountains composed of igneous and metamorphic outcrops. These crops are impervious in nature, but they are intensively jointed, brecciated and faulted. These fractures and fissures act as conduits which control the rainfall water to flow through Wadi Numan, while the impervious basement rocks underneath the alluvium cover of the Wadi are considered as surfaces preventing downward percolation of water. The alluvial deposits capping the basement rocks are composed of sand and gravel alternating with silts to boulders and represent the main aquifer within Wadi Numan.

The present study is a part of a main project, which is currently being conducted by the King Abdulaziz University for the reconstruction and development of the ancient Ain Zubida. The aim of this study is to define the distribution of the ground water around Ain Zubida and to select suitable locations for drilling a number of exploratory wells whose locations are critical for aquifer parameter determination. Therefore, the integration among ground magnetic, resistivity, and seismic refraction methods is used to obtain the most useful results.

\section{Geophysical Field Surveys and Data Processing}

\section{The Total Magnetic Intensity Method}

According to the geology of Wadi Numan, this area consists of different types of rock units with different properties. Each of these rock units has a special magnetic character. In addition, the subsurface structural features, faults, 


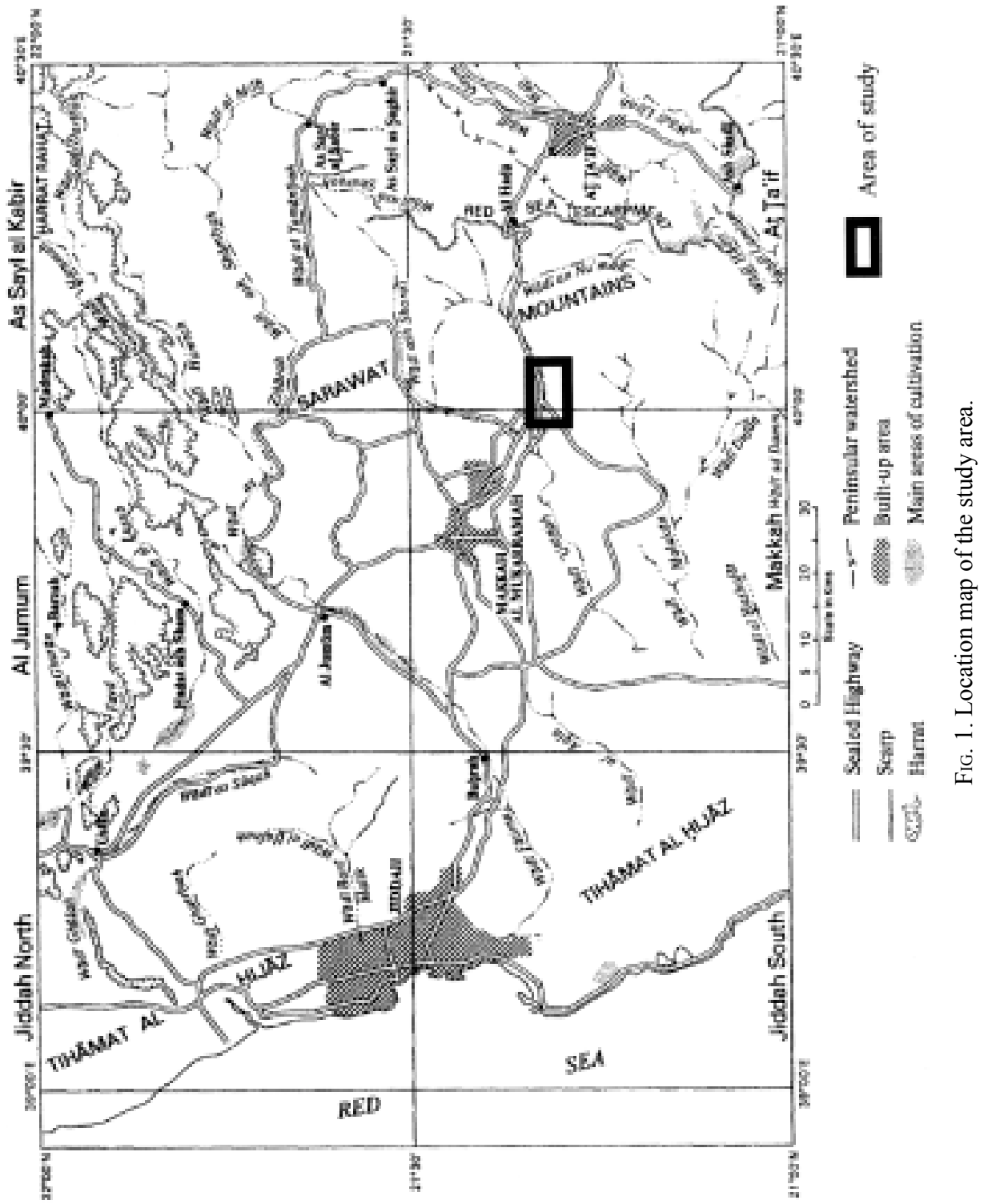




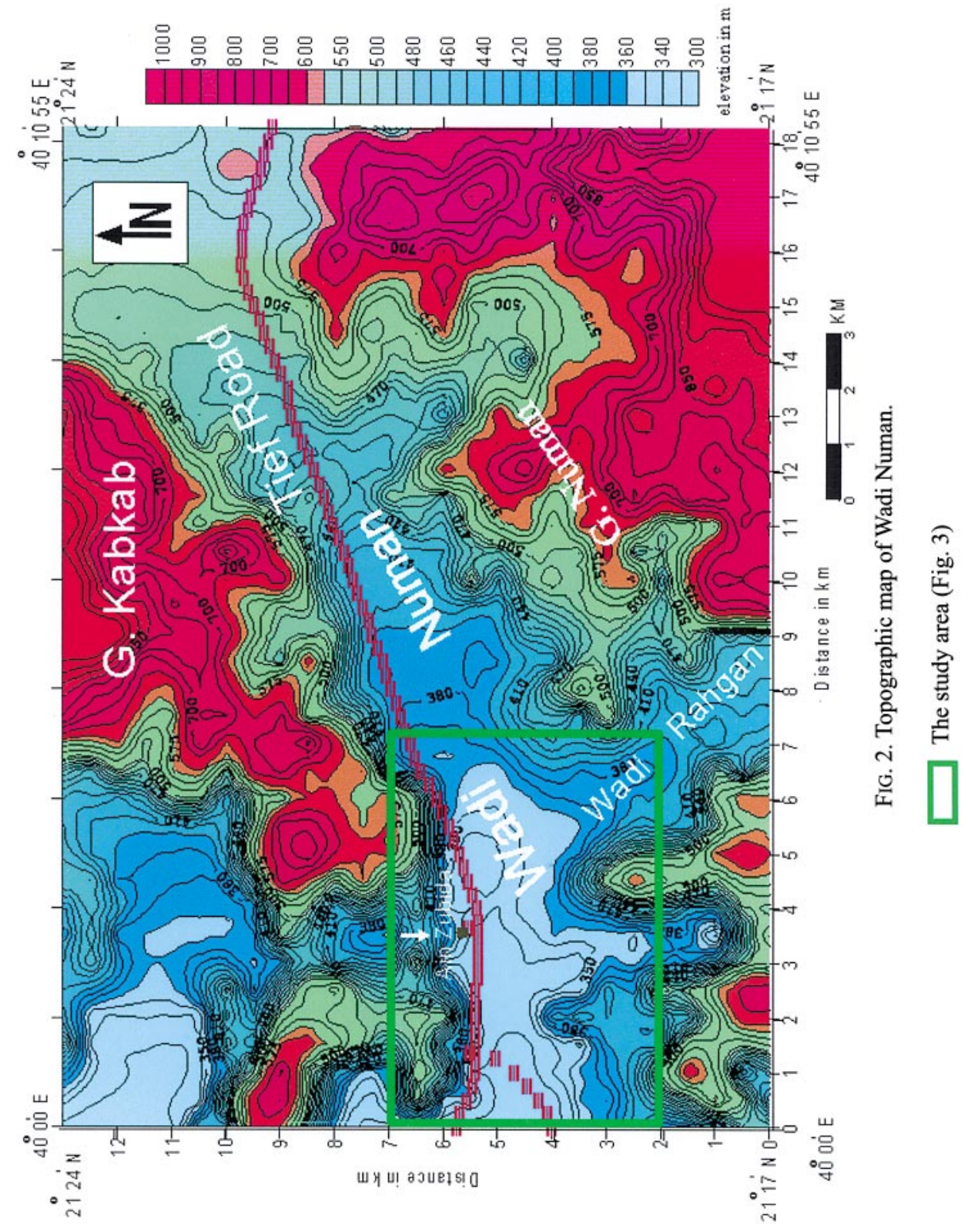


fractures, and dykes, also have distinctive effects on the total magnetic field. Therefore, the main purpose of the magnetic survey is to explore the subsurface structural features along selected profiles.

The total magnetic intensity field survey was conducted along eight profiles extending from south to north across Wadi Numan strike. These profiles are coded 500, 600, 700, 800, 900, 1000, 1100 and 1200 (respectively from W to E, Fig. 3). The proton precision magnetometer model Envi-Mag, Scintrex, Canada, was used. This is a portable magnetometer that can also be used as "base station" magnetometer; its accuracy is about $0.1 \mathrm{nT}$. The field measurements were reduced and plotted as magnetic profiles.

As a result of the total magnetic intensity survey, eight profiles are presented. Each of these profiles, as shown in Figure (4), indicates that the sources of the anomalies beneath the ground surface along the eight profiles are located at various depth levels. Therefore, the frequency analysis technique (Sadek, 1987) was applied to determine the different average depths of these magnetic anomalies. The frequency analysis curve (Fig. 5) exhibits two straight line segments, indicating that the magnetic anomalies are generated at two average depth levels; namely, $25 \mathrm{~m}$ and $121 \mathrm{~m}$, beneath the ground surface of Wadi Numan area. According to these results, the anomaly sources beneath the area under study are classified as; regional anomalies (deep-seated) located at $121 \mathrm{~m}$ average depth; and residual anomalies (shallow or near-surface anomalies) located at $25 \mathrm{~m}$ average depth. To isolate the magnetic response of each of these anomaly groups, matched filtering (Sadek, et al., 1984) was applied using a special window designed according to the parameters determined from the frequency analysis curve of Figure (5). This window is used to calculate the regional magnetic component of each input total magnetic intensity measurement. The residual magnetic component was calculated by subtracting the regional magnetic component from the original total magnetic intensity value. Accordingly, Figures (6) and (7) show the residual and the regional magnetic component stacked profile maps, relatively.

\section{The Vertical Electrical Sounding Method}

The vertical electrical sound survey (VES) was conducted using the Schlumberger array at 62 sites distributed along eight south-north (S-N) trending profiles (Fig. 3). The VES specifications were selected as seven measurements per decade to obtain reasonable data continuity, while half current electrode spacing $(\mathrm{AB} / 2)$ range from $1 \mathrm{~m}$ to $300 \mathrm{~m}$. These specifications allowed considerable depth penetration beneath each sounding site. The survey equipment used was a modern 1200 Watts D.C. resistivity-meter, model ELREC-T (IRIS-instruments, France). 


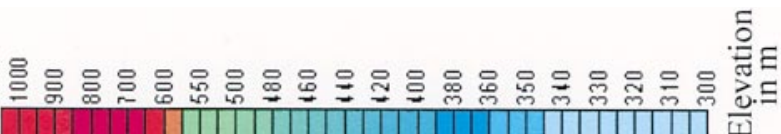

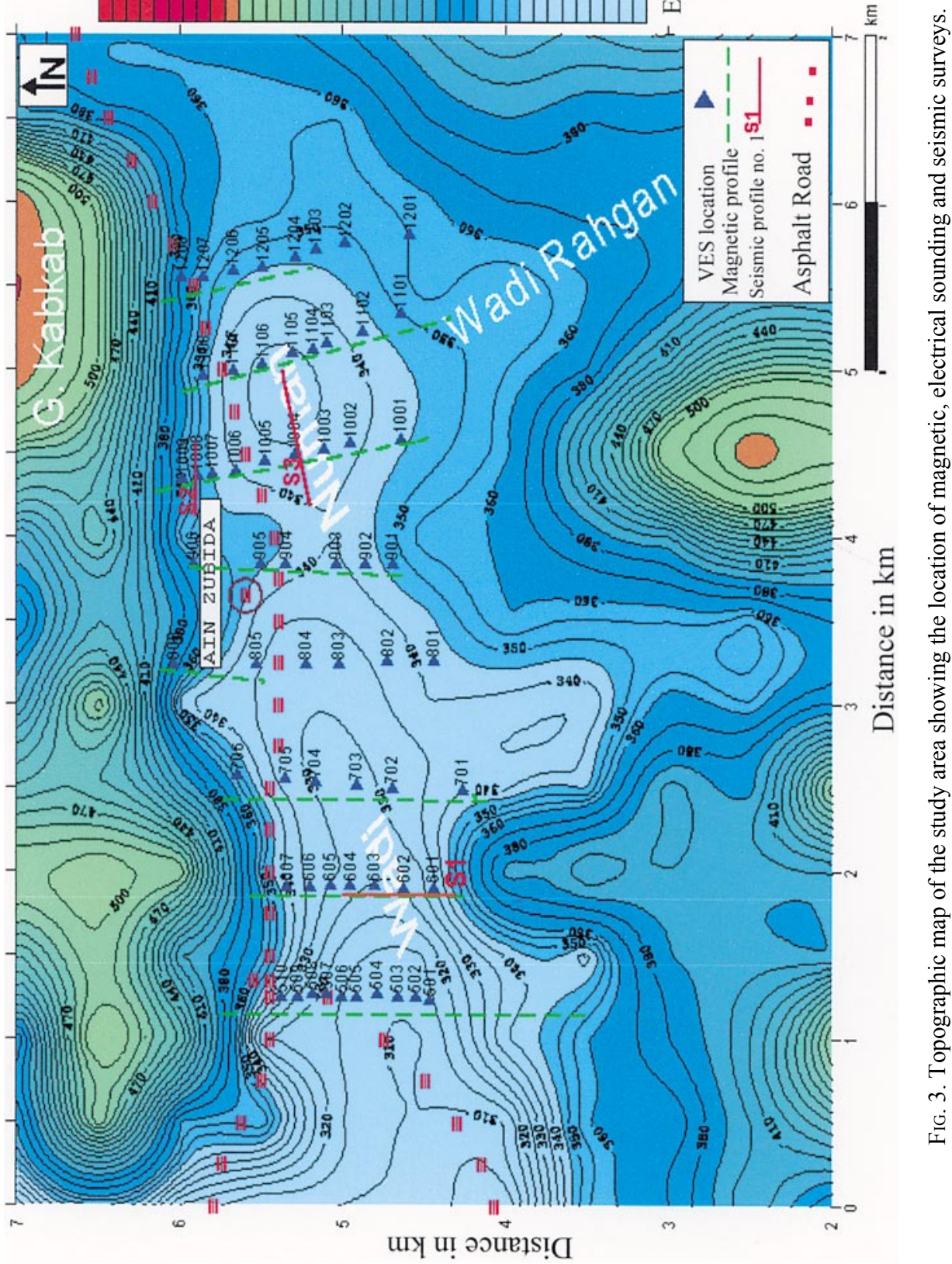




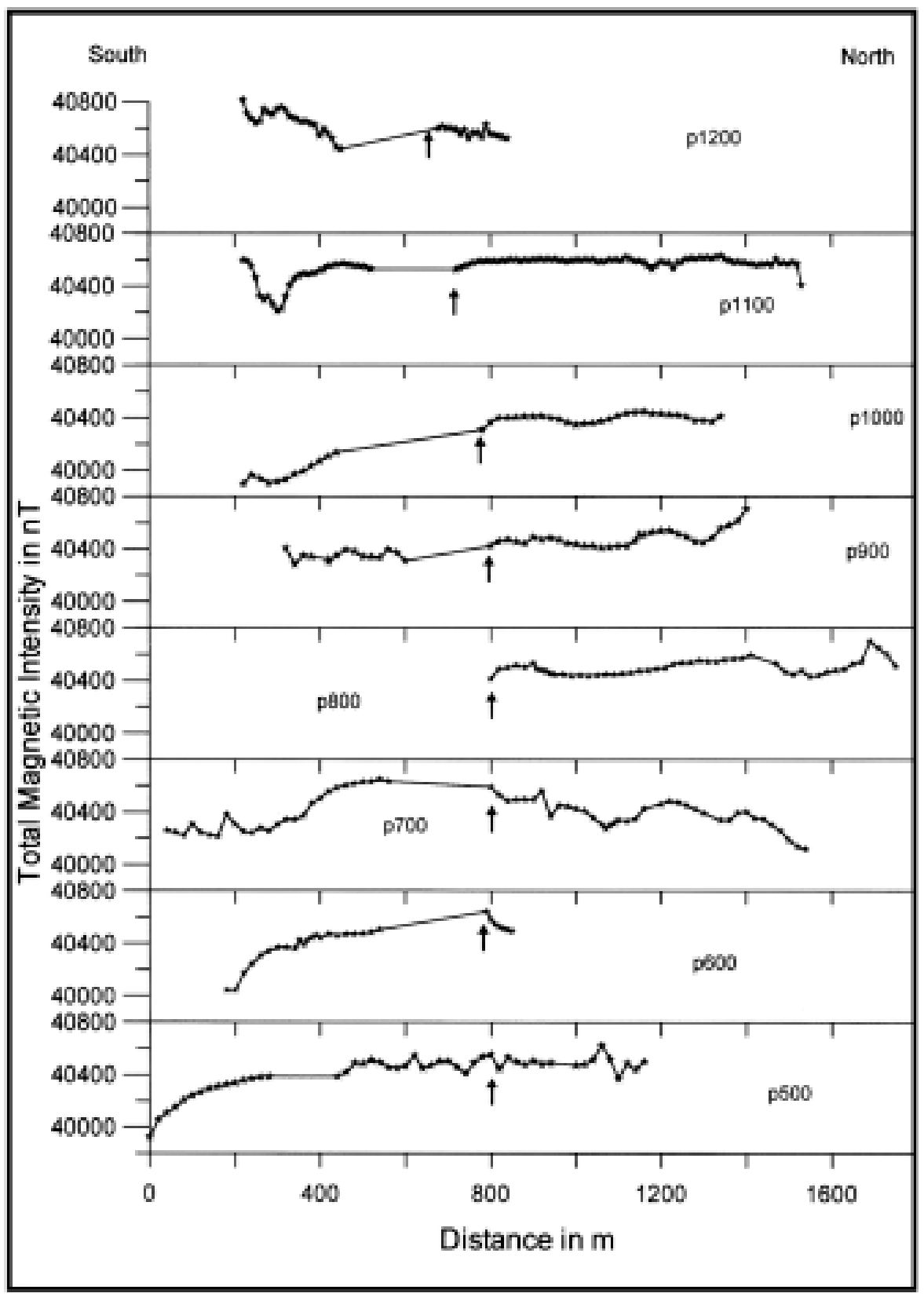

FIG. 4. Total magnetic stacked profile map. Vertical arrow indicates the location of paved road. 


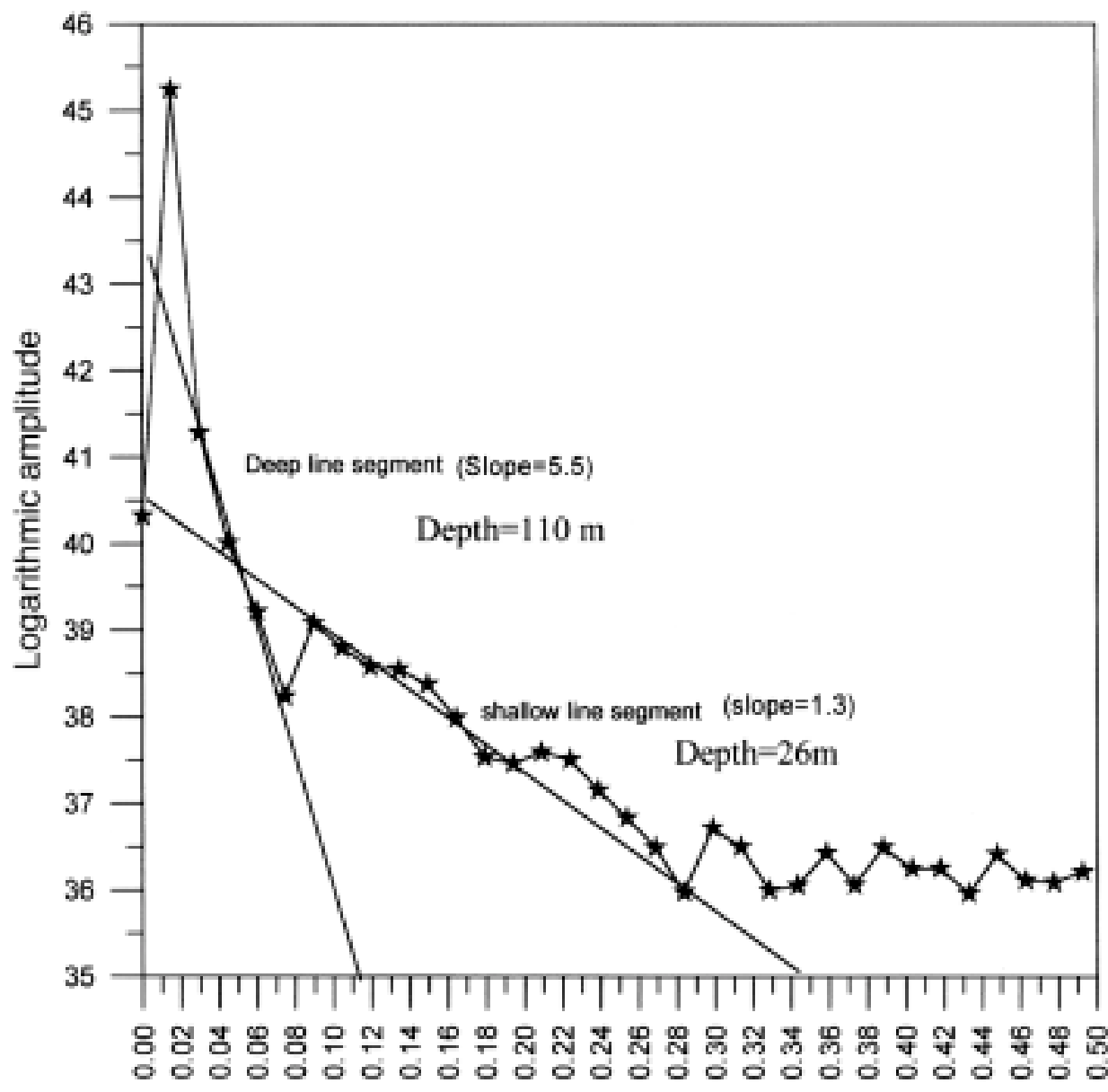

Frequency (cycle / 20 m)

FIG. 5. Frequency analysis curve of the magnetic data. 


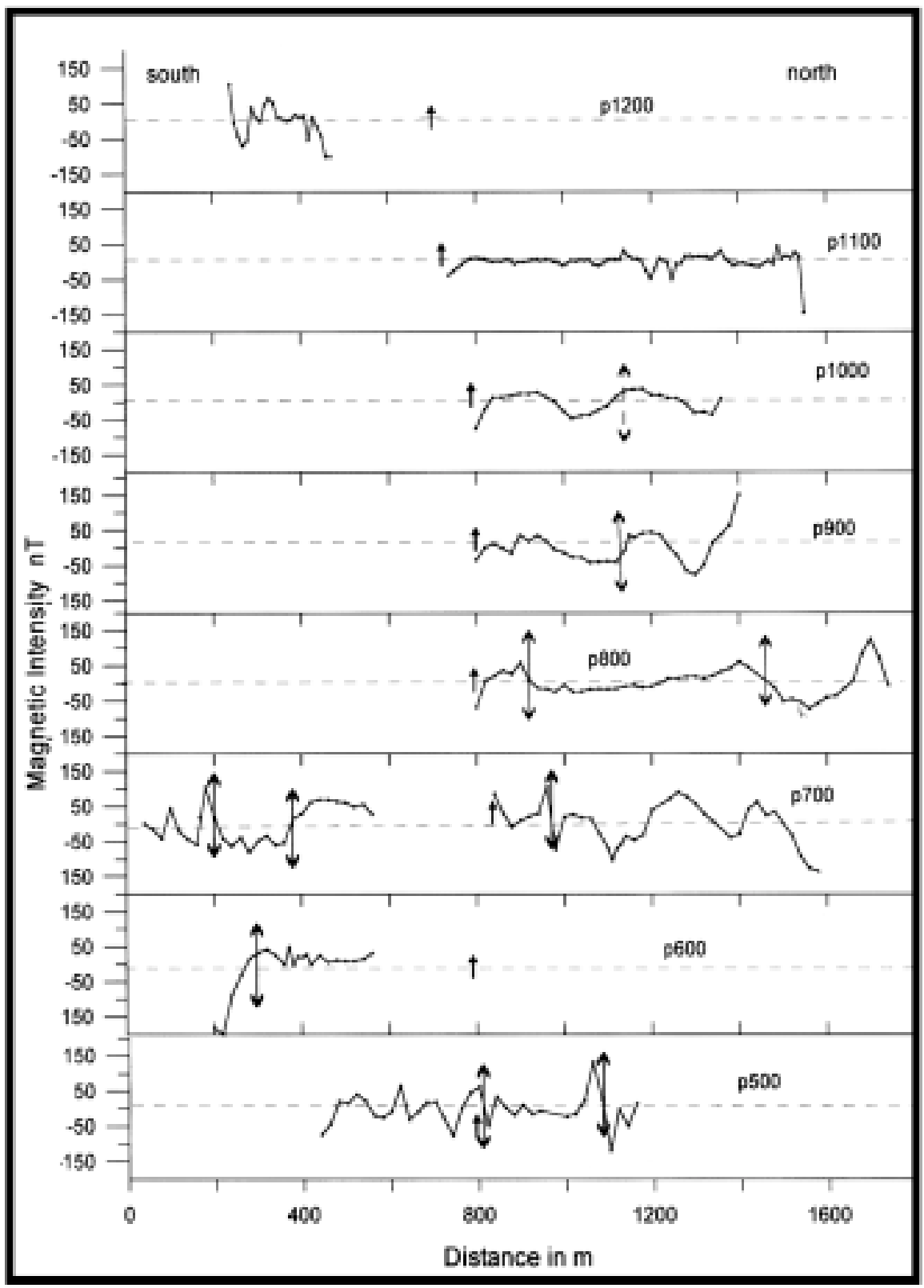

FIG. 6. Residual magnetic component (shallow) stacked profile map. Vertical arrow indicates the location of paved road. 


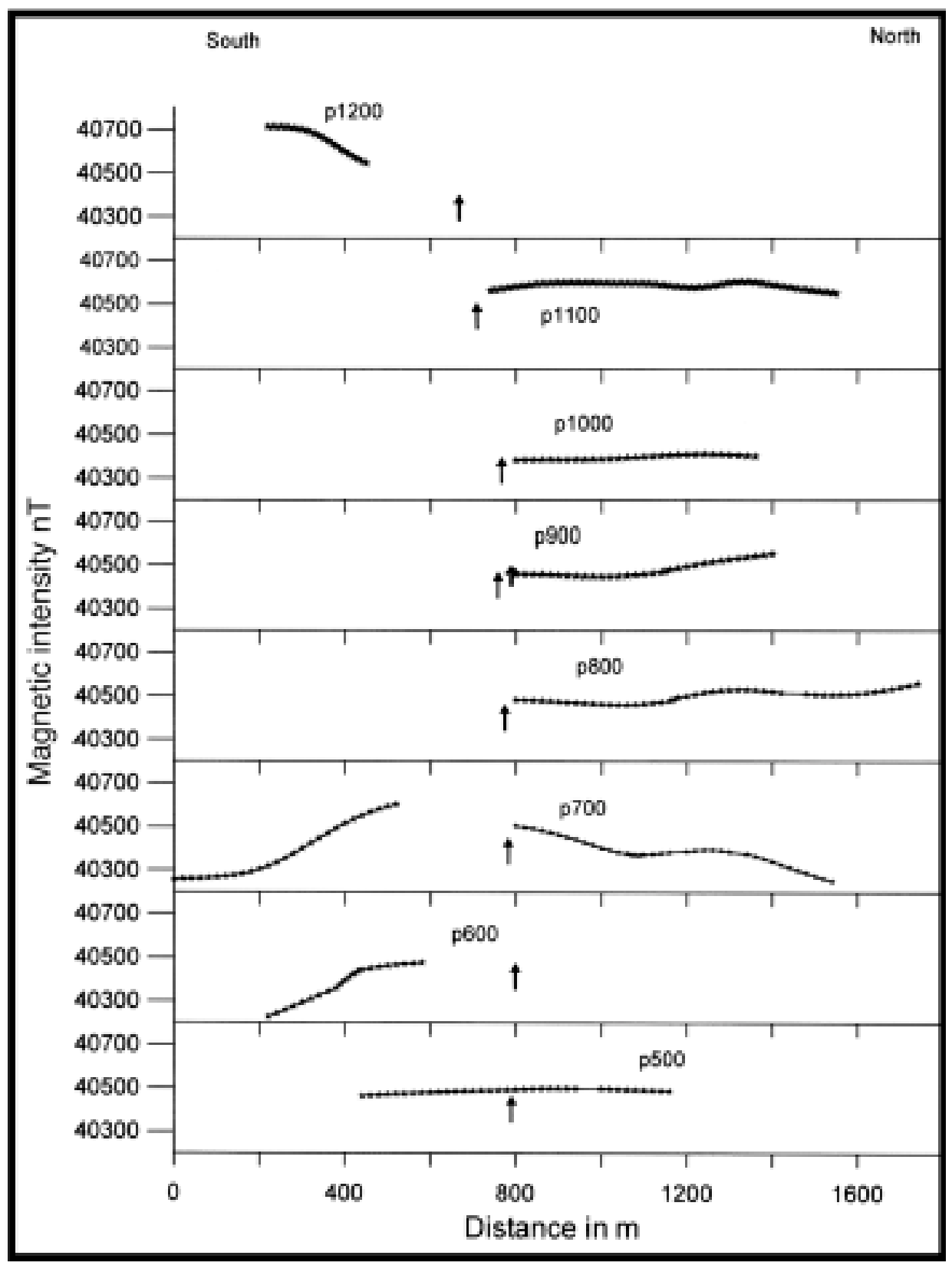

FIG. 7. Regional magnetic component stacked profile map. The vertical arrow indicates the location paved road. 
The collected raw (field) measurements, (Fig. 8a), were reduced and analyzed, and each vertical electrical sounding curve was first compiled to describe the apparent resistivity $\left(\rho_{\mathrm{a}}\right)$ from its different segments. The continuous sounding curve was then smoothed and digitized to produce a six $\left(\rho_{\mathrm{a}}\right)$ readings per decade at half the electrode spacing. The digitized data of the reduced field curve was inverted using the inversion technique developed by Zohdy (1975) to obtain an equivalent-layer model (n-layered model; (Fig. 8b)).

The n-layer models of the different soundings were then used to construct the subsurface true resistivity contour section (SRCS) along each of the eight profiles (Figs. 9 to 16). The contoured values represent the logarithmic values of the resistivity.

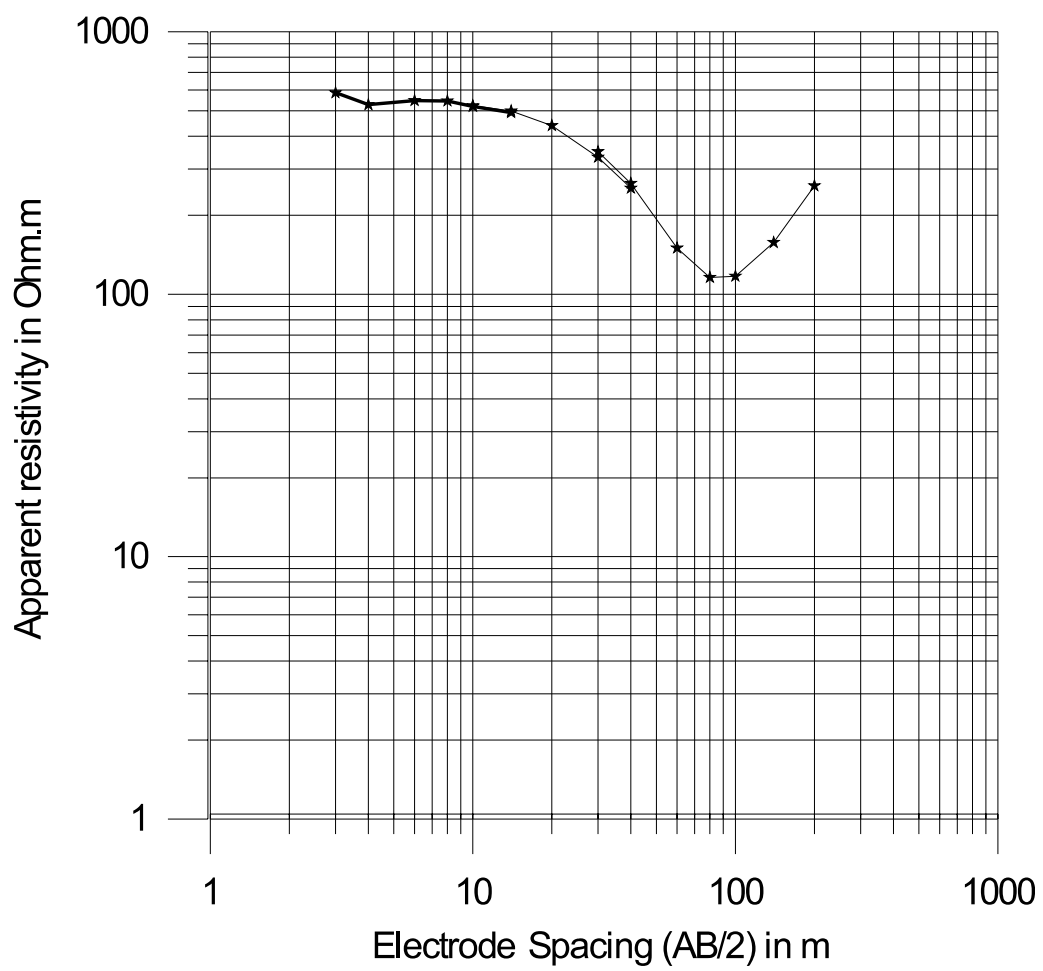

FIg. 8a. Vertical electrical sounding field (VES-1006) curve. 


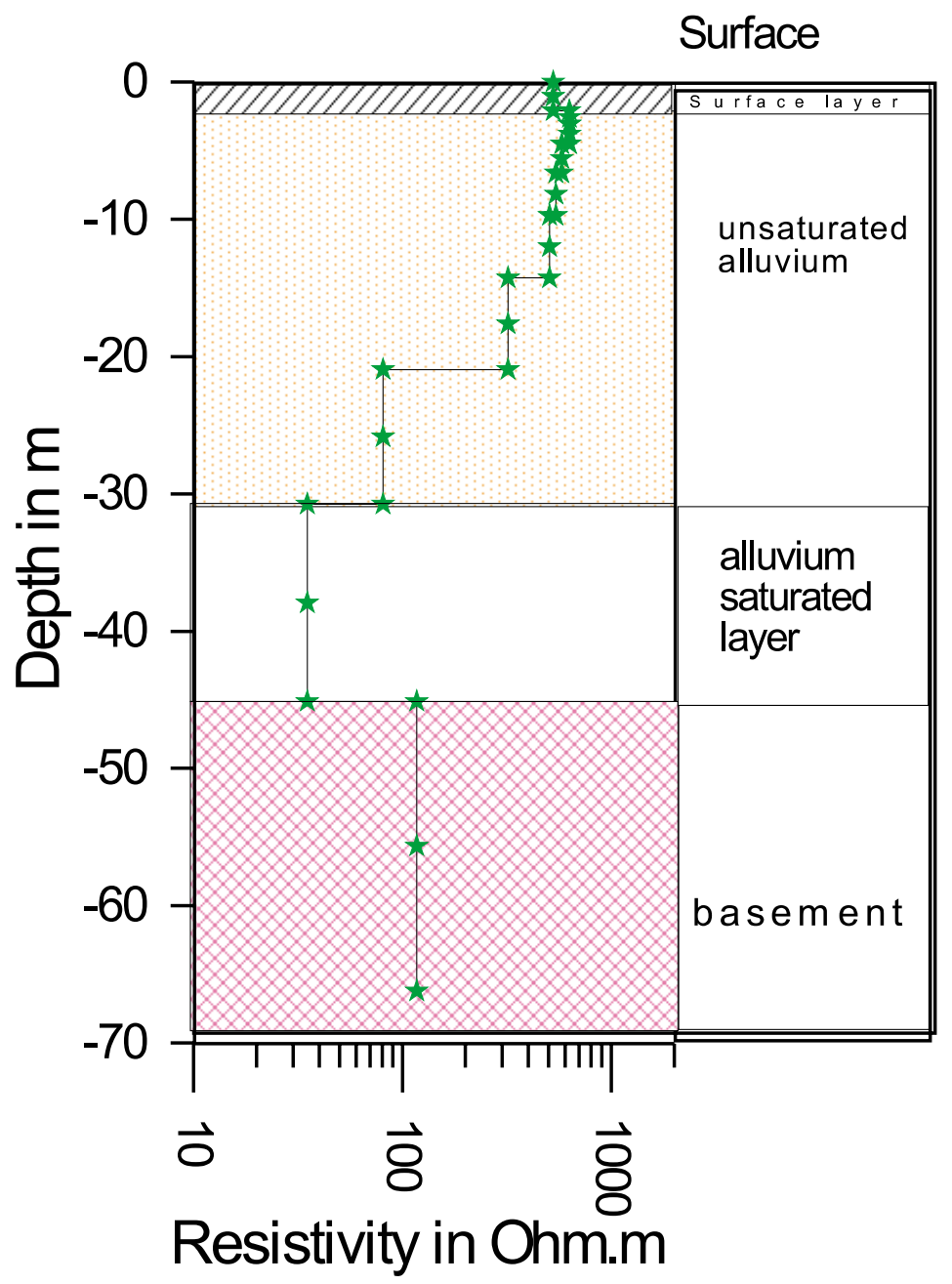

FIG. 8b. The interpreted model of layering as obtained after data analysis and processing (VES1006).

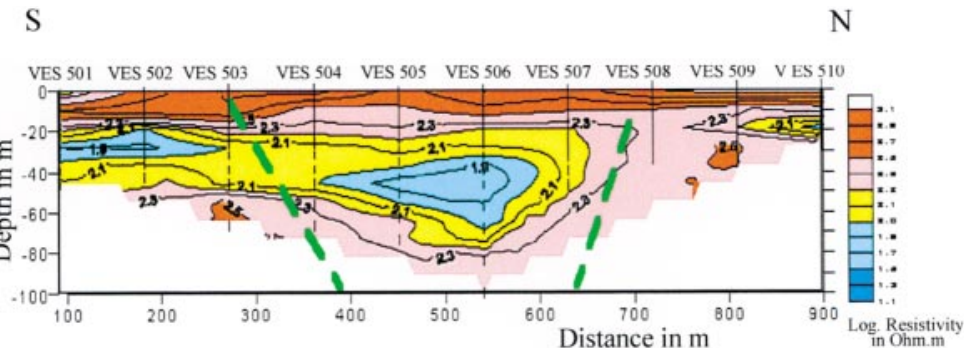

FIG. 9. Subsurface resistivity contour section (SRCS) across profile 500, Wadi Numan. 


\section{The Seismic Refraction Method}

The seismic refraction technique is more suited for shallow investigations, particularly in engineering and hydrogeological applications. Therefore, it is used in the present study to provide information concerning the velocities of elastic waves and to determine the depth (shape) of bedrock and, to some extent, the lithology of inferred refractors (e.g., Sheriff and Geldart, 1982; and Haeni, 1986).

The seismic refraction technique furnishes a convenient approach to the insitu determination of P-wave seismic velocity in rocks which depends on several factors, including porosity, lithology, depth of burial, pressure regime, interstitial fluids, ..., etc. (e.g., Sheriff and Geldart 1982).

In the present study, the sediments are in the form of channels filled with silt, sand and gravels overlying the basement rocks. As the velocity in the watersaturated sediments (about $1.5 \mathrm{~km} / \mathrm{sec}$ ) is generally higher than in dry sediments (generally less than $1.0 \mathrm{~km} / \mathrm{sec}$ ), their contact should act as a good refractor. Based on the foregoing arguments and on the magnetic and geoelectrical findings, we decided that the seismic refraction technique would be effective in determining the thickness of the sediments and, consequently, the irregularity of the basement surface which is of considerable hydrogeological value. Besides, at the expected relatively shallow depths of concern, the seismic technique possesses a superior spatial resulting power and is less ambiguous than either the magnetic or the resistivity techniques.

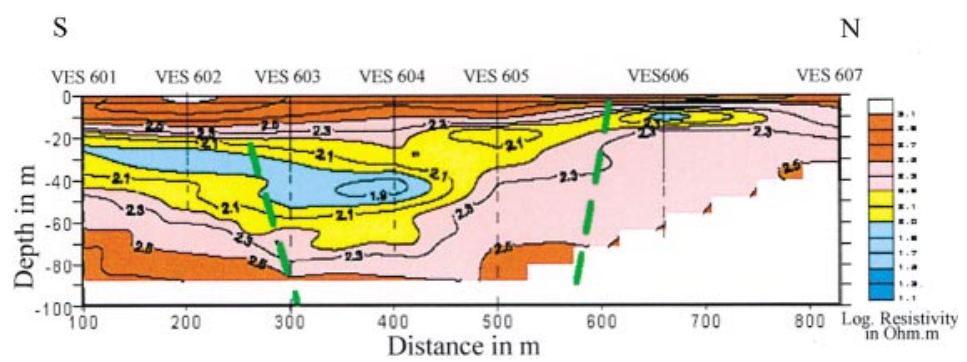

FIG. 10. Subsurface resistivity contour section (SRCS) across profile 600, Wadi Numan.

$\mathrm{S}$

$\mathrm{N}$

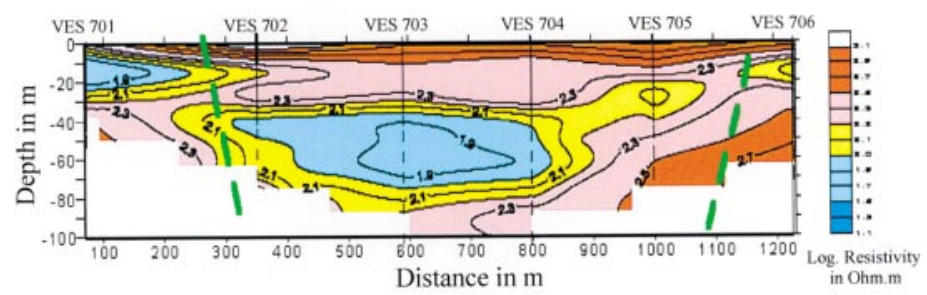

FIG. 11. Subsurface resistivity contour section (SRCS) across profile 700, Wadi Numan. 


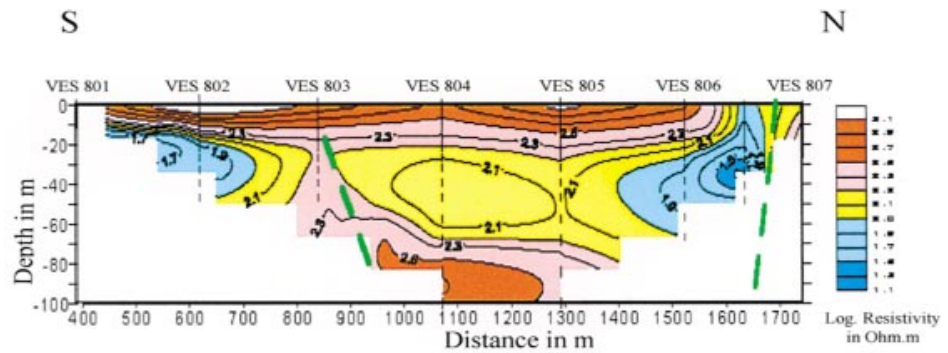

FIG. 12. Subsurface resistivity contour section (SRCS) across profile 800, Wadi Numan.

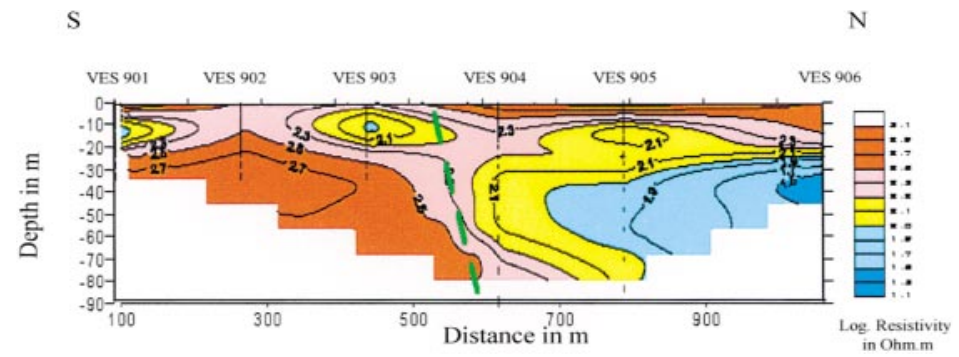

FIG. 13. Subsurface resistivity contour section (SRCS) across profile 900, Wadi Numan.

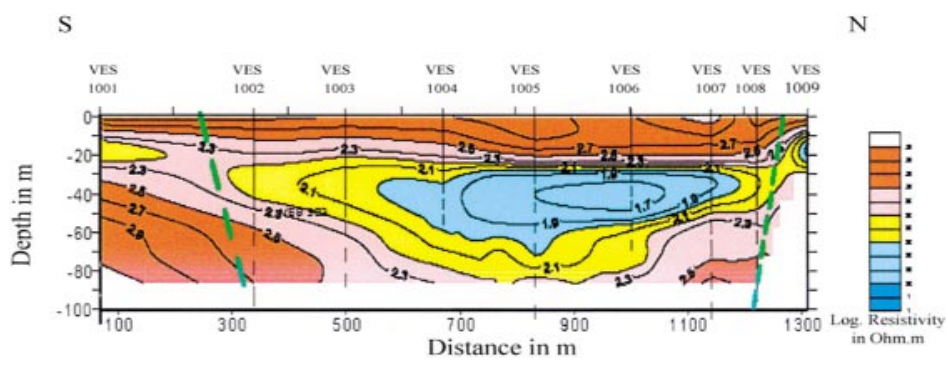

FIG. 14. Subsurface resistivity contour section (SRCS) across profile 1000, Wadi Numan.

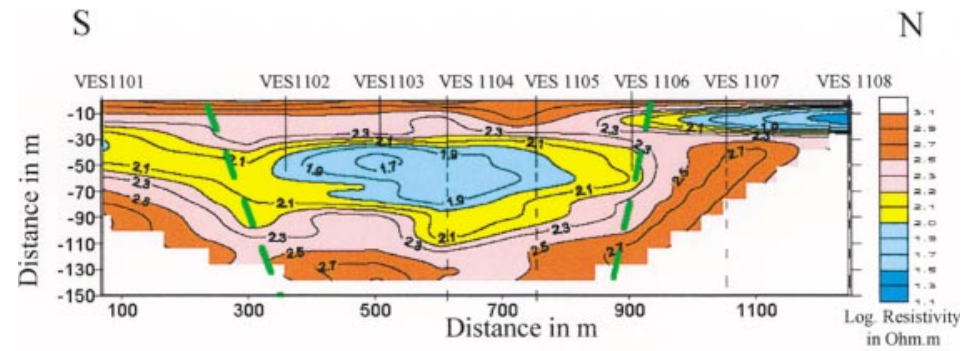

FIG. 15. Subsurface resistivity contour section (SRCS) across profile 1100, Wadi Numan. 


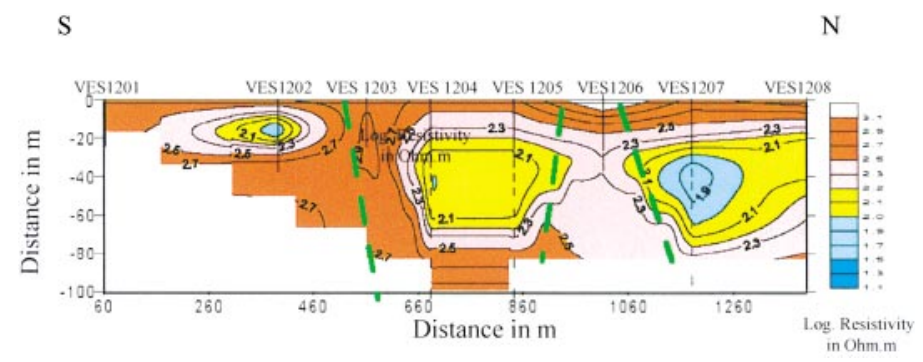

FIG. 16. Subsurface resistivity contour section (SRCS) across profile 1200, Wadi Numan.

The seismic recording system used in the present study was the Bison-7024 digital instrument floating-point (DIFP) signal-stacking seismograph. It is a 24channel seismic data acquisition system (Bison 7000 series, 1990). Vertical component geophones were used to pick up P-wave arriving at the earth's surface. A $7 \mathrm{~kg}$ sledgehammer and an elastic wave generator (EWG-II), with 250 $\mathrm{kg}$ dropping weight, were used for P-wave generation.

Three locations were selected for conducting the seismic survey (Fig. 3) based on the results and recommendations of the magnetic and resistivity surveys. The first seismic profile (S1) was $450 \mathrm{~m}$ long (oriented $\mathrm{S}$ to $\mathrm{N}$ ) and was conducted along the southern part of profile 600 (Fig. 3) passing through VES 601 through VES 604. The second seismic profile (S2) extended $380 \mathrm{~m}$ from E to $\mathrm{W}$. It intersects profile 1001 at the location of VES 1007. The third profile (S3) was conducted south of the Makkah-Taif road (Fig. 3). This profile extended $860 \mathrm{~m}$ west to east and intersects profile 1000 at VES 1004.

The seismic refraction data acquired in the present investigation were inverted using the seismic refraction inversion software "SIPT-2" (Rimrock Geophysics Inc., 1993). The inversion algorithm uses the delay-time method (Pakiser and Black, 1957) to obtain a first approximation depth model. It is then trimmed up by a series of ray tracing and model adjustment iterations to minimize the discrepancies between the field measured arrival times and the corresponding times traced through the $2-1 / 2-\mathrm{D}$ cross sectional depth model (Scott et al., 1968; and Scott and Markiewicz, 1990).

The interpreted subsurface sections underneath the three seismic profiles are shown in Figures (17 to 19) depicting the respective subsurface structures and the associated seismic velocities which can be used to infer lithological and saturation conditions.

\section{Interpretation of The Results}

\section{Interpretation of Magnetic Data}

The integrated interpretation of the total magnetic intensity stacked profile map (Fig. 4), the regional magnetic component stacked profile map (Fig. 7) and 


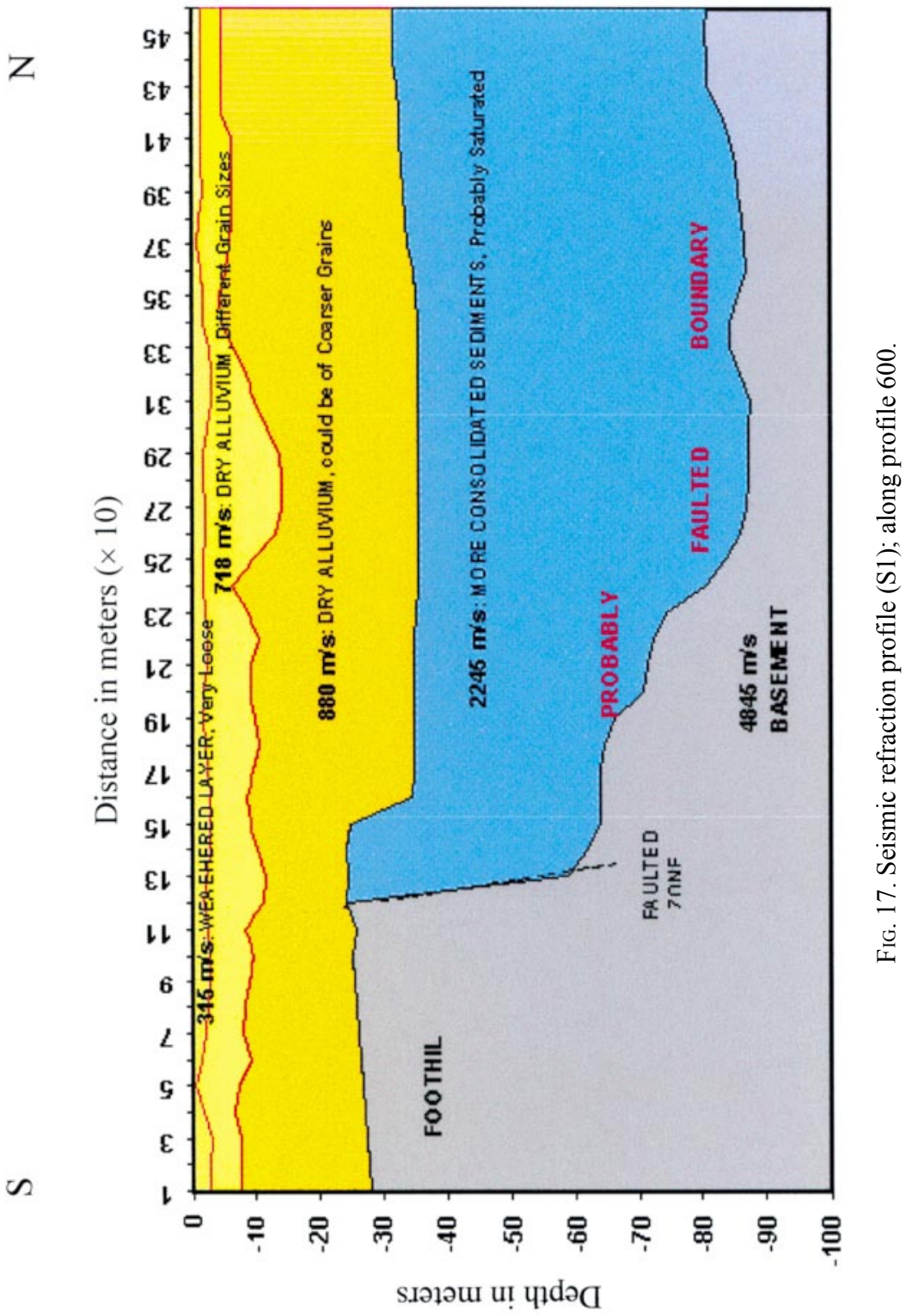




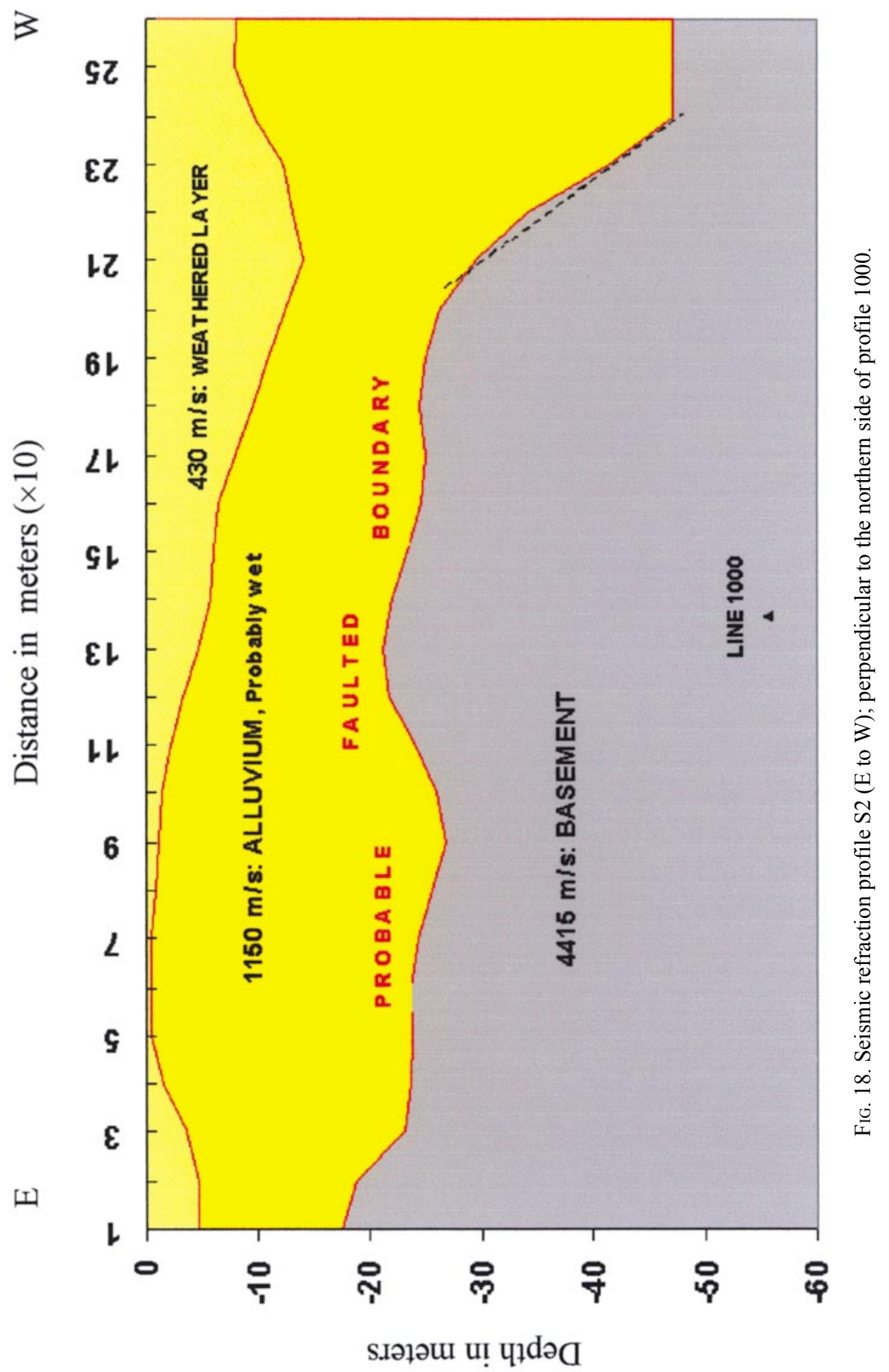




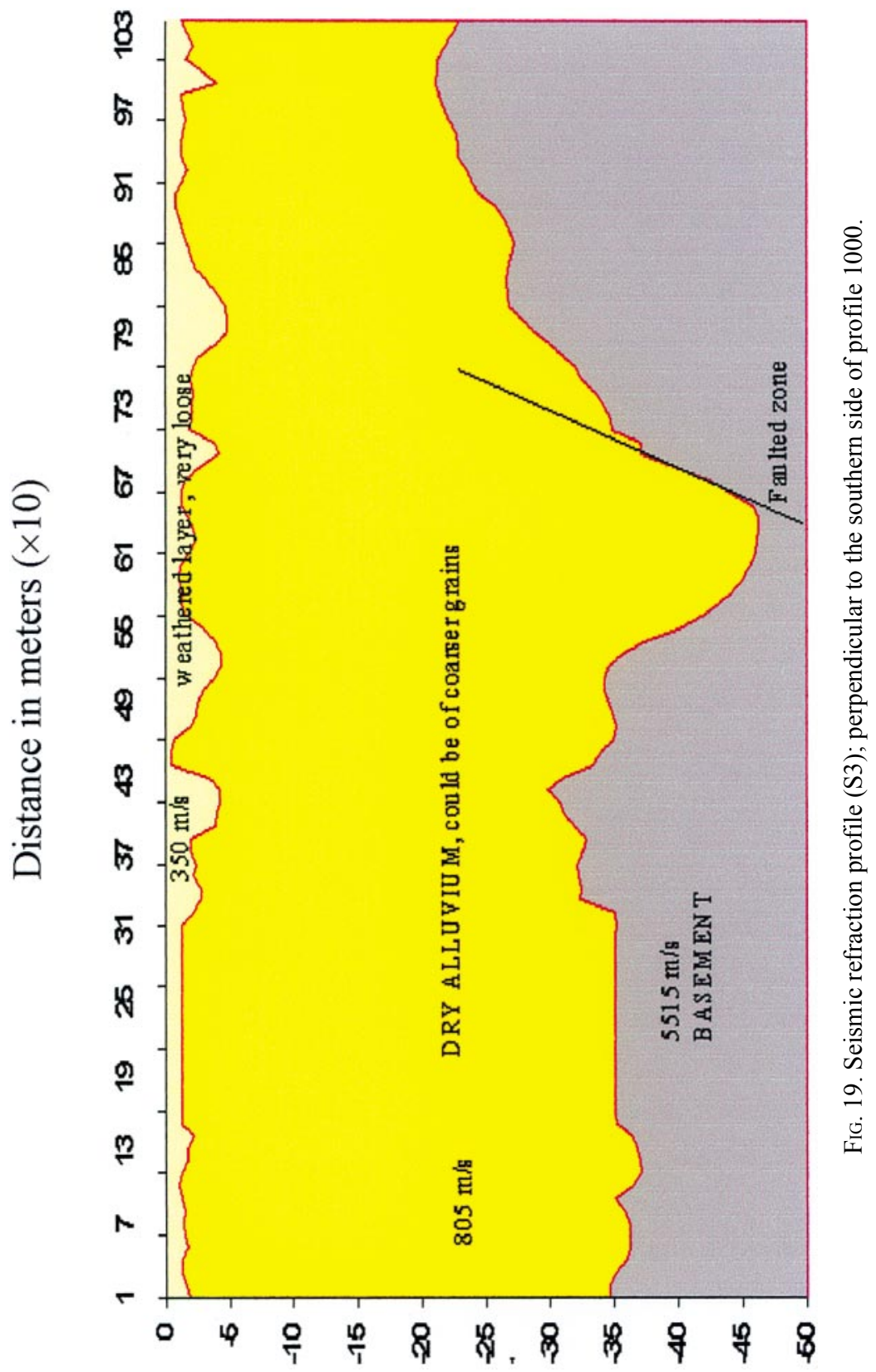


the residual magnetic component stacked profile map (Fig. 6) identifies a number of characteristic magnetic zones. These zones are distributed along each profile with different amplitudes and frequencies. In addition, the correlation of the magnetic characters among the profiles indicates that the area can be classified into three different structural zones. The first zone is represented by the area which includes profiles 500, 600 and 700, while the second zone is represented by the area of profiles 800 and 900 . The third zone is the area which includes profiles 1100 and 1200 . The average magnetic intensity values along each profile are distinctively different. The values along profiles 500, 600 and 700 are 40414,40415 and $40388 \mathrm{nT}$, respectively. The values along profile 800 reach up to $40500 \mathrm{nT}$. On the other hand, the measurements decrease gradually along profiles 900 and 1000, were the values are 40441 and $40275 \mathrm{nT}$, respectively. Again, the values increase to reach 40553 and $40617 \mathrm{nT}$ along profiles 1100 and 1200 , respectively. These variations in magnetic features indicate that the subsurface geological structural setting of Wadi Numan is variable and that the main causative source of magnetic anomalies is the structural relief features of the basement rocks.

The frequency analysis of magnetic data has isolated the high frequency magnetic anomalies as generated by the shallow basement surface at a depth approximately of $25 \mathrm{~m}$ from the lower frequency anomalies caused by a basement surface depth (sediment thickness) approximately of $121 \mathrm{~m}$.

Therefore, the present discussion indicates that the magnetic method can be used, in similar sites, in outlining structural zones controlling ground water distribution, as well as, the relative thickness of the sedimentary cover which is the main target in hydrogeological studies.

\section{Interpretation of Vertical Electrical Sounding (VES) Data}

The variations in the measured electrical resistivity may, in general, be used to differentiate the subsurface into different characteristic zones of different lithologies and water content. In fact, the careful examination of the subsurface resistivity contour sections (Figs. 9-16) does provide details of the subsurface lithology, structural setting and potential ground water occurrences.

The subsurface resistivity contour section SRCS-500 (Fig. 9) reveals that the thickness of the unconsolidated sediments, overlying the basement rocks, beneath VES locations 501, 502, and 503 is almost $30 \mathrm{~m}$. The thickness of these sediments increases beneath VES locations 504, 505 and 506 to reach $45 \mathrm{~m}$, $50 \mathrm{~m}$ and $56 \mathrm{~m}$, respectively. The thickness generally decreases again under VES locations 507, 508, 509 and 510 to reach $32 \mathrm{~m}, 23 \mathrm{~m}, 16 \mathrm{~m}$ and $18 \mathrm{~m}$, respectively. The upper layer of these unconsolidated sediments is characterized 
by its high resistivity (ranging between 394 and 1195 Ohm.m). This layer was recorded in all SRCS's and is underlain by another lower resistivity layer (ranging between 83 and $121 \mathrm{Ohm} . \mathrm{m}$ ). The latter layer is most probably fully or partially saturated with water.

The resistivity contours of the section indicate that Wadi Numan is affected by two E-W trending faults. One of these faults is observed in the southern side of the Wadi (between VES locations 502 and 503) dipping to the north. The second fault, dipping to the south, is observed at the northern side of the Wadi (between VES locations 503 and 504). This structural criterion indicates that Wadi Numan might represent a graben structure. If this was the case, then the second layer of the unconsolidated sediments might horizontally (laterally) be divided into three zones denoted as A, B and C (Fig. 20). Zones A and C are shallower than zone B. Under these structural and geophysical conditions, zone $\mathrm{B}$ might be considered the most significant zone for ground water exploration and, consequently, the suitable sites for drilling exploratory wells would be at VES locations 505 and 506.

The above speculated structural-geophysical subsurface model is indeed exhibited through the remaining subsurface resistivity contour sections, as evidenced by examining Figures (10 through 16). The fact that zone $\mathrm{C}$ is either missing or not recorded along the SRCS-800 (Fig. 12), SRCS-900 (Fig. 13), and SRCS-1200 (Fig. 16) does not contradict the inferred subsurface model, however.

Thus, supporting the magnetic findings, the geoelectrical interpretation indicates that Wadi Numan represents a graben structure. Further, based on the obtained subsurface model, the suitable sites for drilling exploratory wells are: VES locations 505 and 506 (Fig. 9); VES location 604 (Fig. 10); VES location 703 (Fig. 11); VES location 807 (Fig. 12); VES location 906 (Fig. 13); VES locations 1005 and 1006 (Fig. 14); VES locations 1103 and 1104 (Fig. 15); and VES location 1207 (Fig. 16).

\section{Interpretation of Seismic Refraction Data}

The subsurface section (Fig. 17), obtained from the seismic refraction measurements made at the first site S1 (Fig. 3), shows that four sedimentary layers overly the basement. The upper three layers have low seismic velocity ranging from 315 to $880 \mathrm{~m} / \mathrm{sec}$, respectively, with a total average thickness of $30 \mathrm{~m}$. These values of velocity indicate dry, unconsolidated material with different grain sizes (alluvium). Whereas, in the southern $120 \mathrm{~m}$ of the profile, this dry formation directly overlies the basement (velocity $4845 \mathrm{~m} / \mathrm{sec}$ ). In the northern part of the profile, the basement rocks is covered by another sedimentary layer 


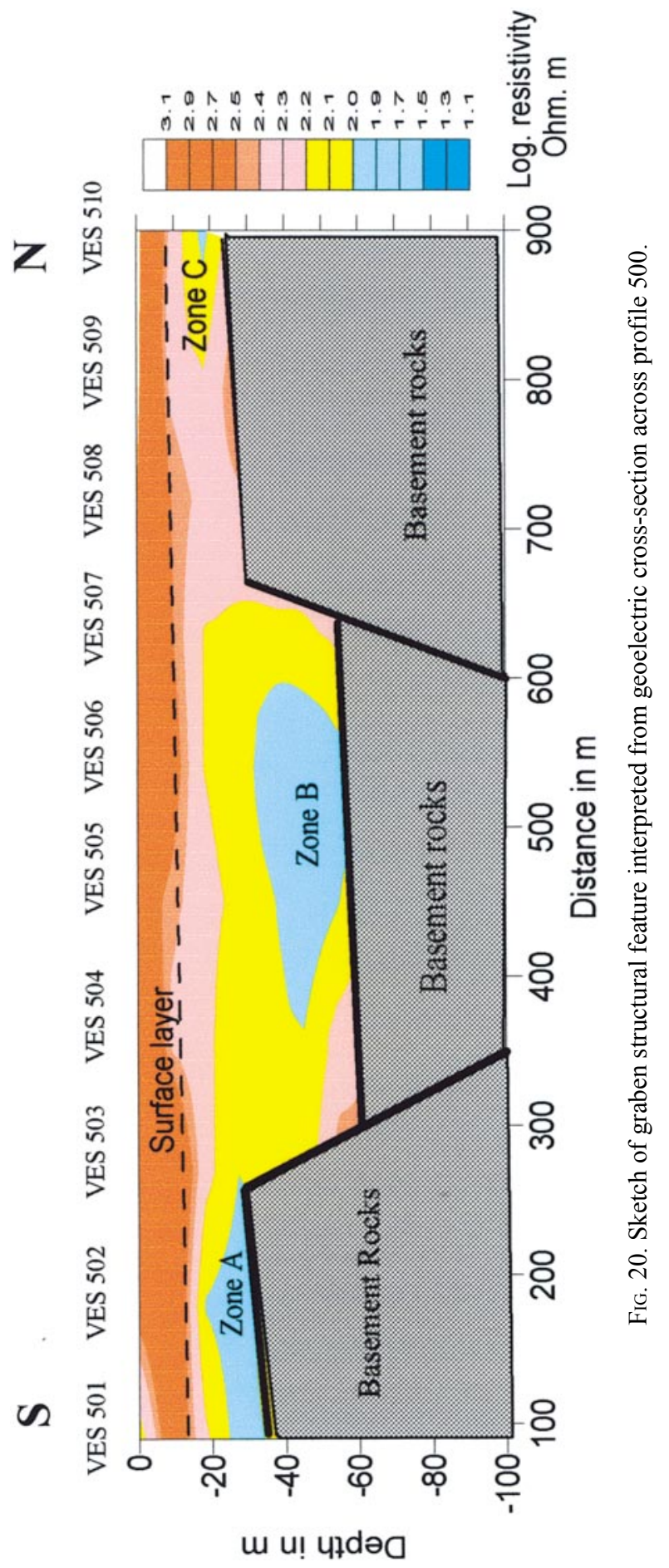


of seismic velocity in the order of $2245 \mathrm{~m} / \mathrm{sec}$ and an average thickness of $55 \mathrm{~m}$. The seismic wave velocity of this layer confirms the result of SRCS-700 that this layer is probably water saturated. Accordingly, the thickness of the sedimentary cover ranges between $30 \mathrm{~m}$ and $85 \mathrm{~m}$. The seismic section also supports the existence of an E-W trending fault with a vertical displacement of about $30 \mathrm{~m}$ and apparently dipping to the north.

The subsurface section (Fig. 18), obtained from the seismic refraction measurements at the second site S2 (Fig. 3), shows that two distinctive alluvial layers cover the basement rocks; their seismic velocites are 430 and $1150 \mathrm{~m} / \mathrm{sec}$, respectively. The velocity of the second layer indicates that this layer is probably wet. The thickness of sedimentary cover is about $22 \mathrm{~m}$ along the eastern $300 \mathrm{~m}$ of the profile. This thickness increases at the western side until it reaches $45 \mathrm{~m}$. The variation in the depth of basement rock surface indicates that there is an N$\mathrm{S}$ trending fault with a vertical displacement of the order of $25 \mathrm{~m}$ and apparently dipping to the west.

At the third side, the subsurface section (Fig. 19), obtained from the seismic refraction measurements of profile S3 (Fig. 3), shows that the sedimentary cover is composed of two different layers having seismic velocities of 320 and $805 \mathrm{~m} / \mathrm{sec}$, respectively. The velocity of the second layer indicates that this layer was dry (during the survey time). The total thickness of the sedimentary cover in the western $550 \mathrm{~m}$ of the profile is about $35 \mathrm{~m}$. This thickness increases to reach $45 \mathrm{~m}$ at a distance of $610 \mathrm{~m}$ from the west, and decreases to $22 \mathrm{~m}$ at a distance of $980 \mathrm{~m}$ from the west.The variation of thickness of sediments overlying the basement rocks indicates that there is an N-S trending fault with a vertical displacement of about $13 \mathrm{~m}$ and apparently dipping to the west.

\section{Conclusion}

To accomplish the aim of this study, the ground magnetic, resistivity and seismic refraction methods were integrated to outline the ground water occurrences beneath the area around Ain Zubida.

The ground magnetic survey was conducted along eight profiles across Wadi Numan. The frequency analysis of magnetic data indicates that the depth of basement rock surface in the area under investigation ranges between 25 and $121 \mathrm{~m}$. Also, the stacked profile maps of the total magnetic intensity, residual magnetic component and regional magnetic component are used to delineate the main structural zones and the relative thickness of sedimentary cover controlling ground water distribution.

The vertical electrical sounding survey was conducted at 62 selected sites along eight profiles. Careful examination of the subsurface resistivity contour 
sections constructed for each group of soundings along each profile, and their comparison with the results of seismic sections indicates that:

1 - Both methods precisely determine the geometrical configuration and the physical properties of the subsurface layers constituting the sedimentary cover overlying the basement rocks. The results also assign the unconsolidated sediments characteristics.

2 - The unconsolidated sediments can be distinguished into two distinctive layers of different resistivity values. The upper one has relatively high resistivity values (ranging between 300 and 1000 Ohm.m) and low seismic velocities (ranging between 315 and $880 \mathrm{~m} / \mathrm{sec}$ ) and corresponds to a layer of dry unconsolidated sands, boulders and alluvial deposits. The second layer, overlying the basement rocks, is characterized by its relatively low resistivity values (ranging between 30 and $300 \mathrm{Ohm} . \mathrm{m}$ ) and its relatively high seismic velocities $(1150 \mathrm{~m} / \mathrm{sec}$ at $\mathrm{S} 1$ and $2245 \mathrm{~m} / \mathrm{sec}$ at S2). These latter values of the unconsolidated sediments indicate that this layer is saturated with ground water.

3 - The suitable sites for drilling exploratory wells are VES locations 505, $506,604,703,807,906,1005,1006,1103,1104$ and 1207, with the most suitable sites being VES locations 703, 807, 906, 1005, 1006, and 1104 .

The interpreted subsurface geoelectric and seismic refraction sections indicate that Wadi Numan may be considered as a graben structure, which represents the main target of water accumulation. The seismic refraction method defines the southern E-W trending fault of this graben structure and delineates its dip direction (to the north) and vertical displacement $(\sim 30 \mathrm{~m})$. In addition, N-S trending faults cutting across Wadi Numan are recorded in two sites at the zone of intersection of Wadi Numan with Wadi Rahgan, one is located in the southern side and the other is located in the northern side of Wadi Numan. These faults dip to the west and have different vertical displacements $(13 \mathrm{~m}$ at the southern site and $25 \mathrm{~m}$ at the northern site). These N-S trending faults construct suitable natural environment for developing an aquifer underneath the surface of this part of the Wadi. Finally, the distribution of the ground water occurrences can be inferred from the integration of this information.

\section{Acknowledgement}

This work has been supported by the project funded by His Royal Highness Prince Abdullah Bin Abdulaziz, The Crown Prince of the Kingdom of Saudi Arabia, and the Deputy Prime Minister and the President of the National Guard, to whom we are deeply grateful and thankful. We also would like to thank King Abdulaziz University and the Faculty of Earth Sciences for their support and encouragement during this research. The authors would also like to thank Dr. Omer Abu Rziza, the Principal Investigator of the Ain Zubida Project. The au- 
thors wish to express their gratitude to Dr. Mohamad A. El Difrawy for his helpful comments, valuable criticisms and professional editing. Also, we are very thankful to the effort and enthusiasm of the staff members, Prof. Ahmad G. Hussain, Mr. Noor El Deen M. Dameery, and Mr. Hussain El-Harbi. Thanks are also due to Mr. Hassan Ben Ali Meshara, Mr. Fayz El Malki, and Mr. Khaled El Zahrani for their help during the execution of this work.

\section{References}

Bison Instruments, Inc. (1990) Bison 7000-series, Digital instantaneous floating point (DIFP) seismograph, Instruction Manual, Bison Instruments, Inc., Minneapolis, USA.

Brown, G.F., Jackson, R.O., Bogue, R.G. and MacLean, W.H. (1963) Geology of the Southern Hijaz Quadrangle, Kingdom of Saudi Arabia: Saudi Arabian Directorate General of Mineral Resources Miscellaneous Geologic Investigations Map I-210A, 1:500,000 scale.

Haeni, F.P. (1986) Application of seismic refraction methods in ground water modeling studies in New England, Geophysics, 51: 236-246.

Pakiser, L.C. and Black, R.A. (1957) Exploring for ancient channels with the refraction seismograph, Geophysics, 22: 32-47.

Rimrock Geophysics Inc. (1993) User's guide to: SIP SHELL (1991-1993), SIPIN and SPEDT V-4.0 (1993) for creating and editing seismic refraction data files, BSIPIK V-4.0 (19881993 ) for interpreting seismic refraction data using modeling and iterative ray tracing technique, Rimrock Geophysics Inc., USA.

Sadek, H.S. (1987) Profile frequency analysis of potential field data using Filon Fourier Transforms with basic software. Geophysical data inversion methods and applications. Theory and Practice of Applied Geophysics V. 4, Charles Ofoegbu and Andreas Vogel (eds). Berlin, Germany, 155-177.

Scott, J.H. and Markiewicz, R.D. (1990) Dips and Chips - PC programs for analyzing seismic refraction data: Proc. Symposium on the Application of Geophysics to Engineering and Environmental Problems (SAGEEP, 1990), Colorado, USA, 157-200.

Scott, J.H., Lee, F.T., Caroll, R.D. and Robinson, C.S. (1968) The relationship of geophysical measurements to engineering and construction parameters in the Straight Greek tunnel pilot boring, Colorado, Int. J. Rock. Mech. Min. Sci., 5: 1-30.

Sheriff, R.E. and Geldart, L.P. (1982) Exploration Seismology. Vol. I, History, Theory, and Data Acquisition; Vol. II, Data Processing and Interpretation, Cambridge University Press.

Sadek, H.S., Rashad, S.M. and Blank, H.R. (1984) Spectral analysis of aeromagnetic profiles for depth estimation: principles, software, and practical application. USGS-OF-04-27.

Zohdy, A.R. (1989) A new method for automatic interpretation of Schlumberger and Wenner sounding curves. Geophysics, 54: 245-253.

Zohdy, A.R. (1975) Automatic interpretation of Schlumberger sounding curves using modified Dar Zarrouk functions, U.S. Geological Survey Bull., 1313 E., 39 p. 
التعرف على وجود المياه الجموفية تحت سطح المنطقة المحيطة بعين زبيدة باستخدام طرق المغناطيسية والسبر بالمقاومية الكهربية

$$
\text { و السيزمية الانكسارية }
$$

طلال علي مختار ، حمدي إسماعيل السيد حسانين و محمد مأمون السعيد

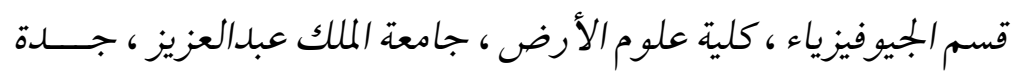

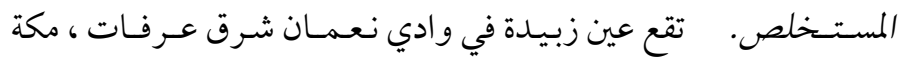

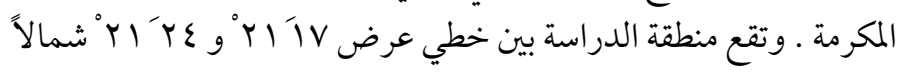

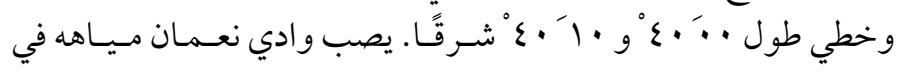

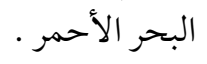

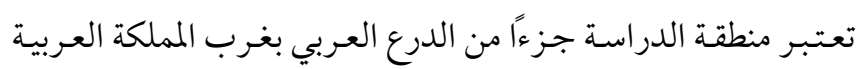

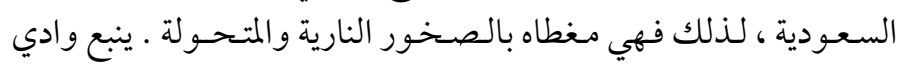

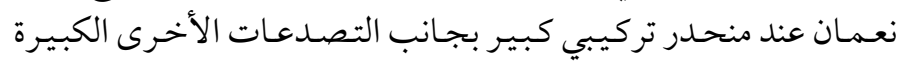
والصغيرة المتشترة في وادي نعمان و المناطق المجاورة له ه.

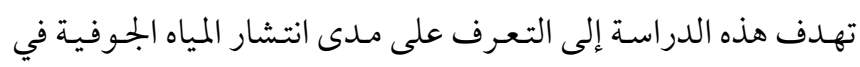

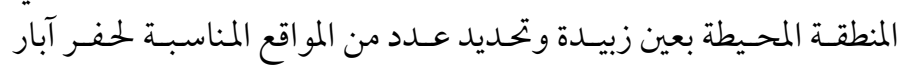
اختبارية.

لهذا استخدمت الطرق المغناطيسية وسبر المقاومية الكهربية والسيزمية الانكسارية متكاملة للحصول على نتائج مفيدة .

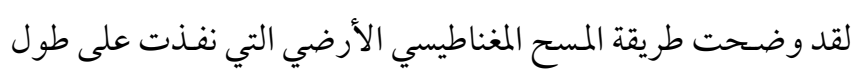

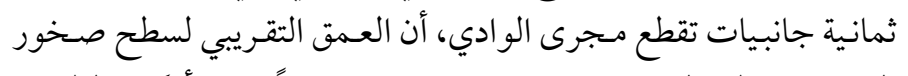

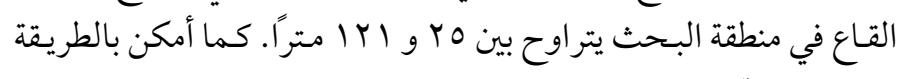

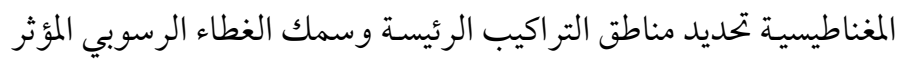
في توزيع المياه الجوفية.

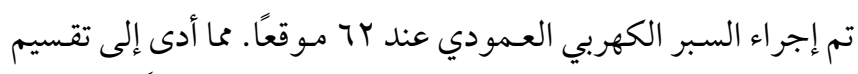
الرسوبيات غير المتماسكة التي تغطي سطح صخور القاع، طبقًا لمقاوميتها 
الكهربية، إلى منطقتين ميزتين. الطبقة العليا تتميز بقيم مقاومية كهربية

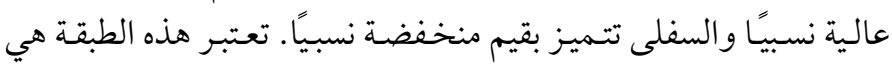
الطبقة المتوقع تشبعها بالمياه.

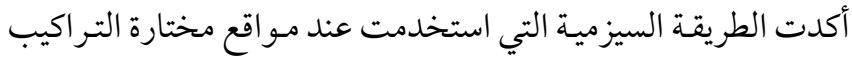

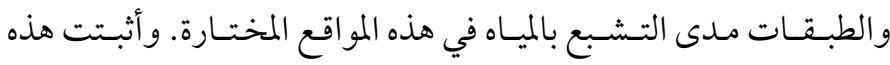

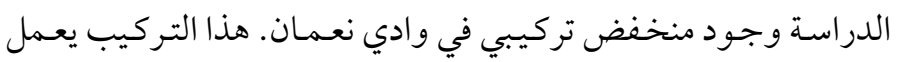

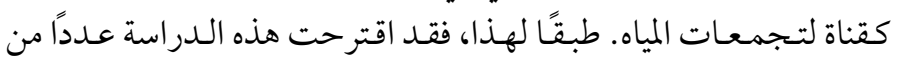

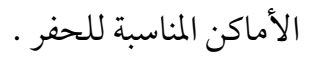

